\title{
DEEP STRUCTURE OF SOUTH KAMCHATKA ACCORDING TO GEOPHYSICAL DATA
}

\author{
Yu. F. Moroz ${ }^{1,2}$, L. I. Gontovaya ${ }^{1}$ \\ ${ }^{1}$ Institute of Volcanology and Seismology, Far East Branch of RAS, Petropavlovsk-Kamchatsky, Russia \\ ${ }^{2}$ Geological Institute, Siberian Branch of RAS, Ulan-Ude, Russia
}

\begin{abstract}
Differences have been discovered in the deep structures of North and South Kamchatka, which raises a question about a boundary between these regions. This problem has been studied on the basis of the seismologic, inverse seismic tomographic (P-waves) and geoelectrical data obtained in recent years, as well as the information on magnetometry, gravimetry, tectonics and magmatism of the study area. Comprehensive analysis of the geological and geophysical data shows differences in the structure of the crust and upper mantle in North and South Kamchatka and common features of the deep structures of South Kamchatka and the Kuril Islands. A presumed boundary between North and South Kamchatka is related to the zone of transverse deep faults crossing the peninsula. It is evidenced by P-wave velocity anomalies at different levels of the lithosphere. This fault zone is associated with a change in the geometry and strike of the high-velocity focal layer, and reflected in the modern tectonic plan as the PetropavlovskMalkinsky zone of transverse dislocations. In this zone, the Avacha-Koryak group of modern volcanoes is also NWoriented. We propose a geoelectric model showing the depths along the profile constructed across the zone. In its deep part, the model includes sub-vertical anomalies of increased electrical conductivity. The anomalies are related to deep faults. Increased electrical conductivity may be due to the presence of magmatic melts feeding volcanoes. The results obtained in our study give evidence of the common features of the deep structures of South Kamchatka and the Kuril island arc and demonstrate the differences between the deep structures of North and South Kamchatka, being separated by the zone of faults, which may penetrate into the upper mantle. It is suggested that the identified features in the South Kamchatka structure are due to deep processes taking place not only at the side of the Pacific Ocean, but also at the southern margins of the Sea of Okhotsk. These findings are of interest for geodynamics, volcanology, tectonics and other Earth sciences.
\end{abstract}

Key words: seismology; seismic tomography; geoelectrics; seismic velocity rate; electrical conductivity; earthquake; volcano; hydrothermal solution; magmatic melt

\section{RESEARCH ARTICLE}

Received: June 27, 2018

Revised: November 7, 2018

Accepted: November 14, 2018

For citation: Moroz Yu.F., Gontovaya L.I., 2018. Deep structure of South Kamchatka according to geophysical data. Geodynamics \& Tectonophysics 9 (4), 1147-1161. doi:10.5800/GT-2018-9-4-0387.

Для цитирования: Мороз Ю.Ф., Гонтовая Л.И. О глубинном строении Южной Камчатки по геофизическим данным // Геодинамика и тектонофизика. 2018. Т. 9. № 4. С. 1147-1161. doi:10.5800/GT-2018-9-4-0387. 


\title{
О ГЛУБИННОМ СТРОЕНИИ ЮЖНОЙ КАМЧАТКИ ПО ГЕОФИЗИЧЕСКИМ ДАННЫМ
}

\author{
Ю. Ф. Мороз ${ }^{1,2}$, Л. И. Гонтовая ${ }^{1}$ \\ ${ }^{1}$ Институт вулканологии и сейсмологии ДВО РАН, Петропавловск-Камчатский, Россия \\ ${ }^{2}$ Геологический институт СО РАН, Улан-Удэ, Россия
}

\begin{abstract}
Аннотация: Глубинное строение Северной и Южной Камчатки представляется различным, возникают даже вопросы о границе между ними. Для их решения использованы данные сейсмологии, инверсной сейсмотомографии на объемных Р-волнах и геоэлектрики, полученные в последние годы, а также сведения по магнитометрии, гравиметрии, тектонике и магматизму. На основе комплексного анализа геолого-геофизических данных установлено различие в строении земной коры и верхней мантии Северной и Южной Камчатки и показана общность глубинных структур Южной Камчатки и Курильских островов. Определена возможная граница между Северной и Южной Камчаткой, связанная с зоной поперечных глубинных разломов, пересекающих полуостров. Она проявляется в поведении скоростных аномалий на различных уровнях литосферы. С этой зоной связано изменение геометрии и простирания высокоскоростного фокального слоя. Данная разломная зона находит отражение в современном тектоническом плане в виде Петропавловск-Малкинской зоны поперечных дислокаций. Здесь расположена Авачинско-Корякская группа современных вулканов, также ориентированная в северо-западном направлении. Приводится глубинная геоэлектрическая модель по профилю, выполненному вкрест этой зоны. Глубинная часть модели содержит субвертикальные аномалии повышенной электропроводности. Они связываются с глубинными разломами. Повышенная электропроводность может быть обусловлена наличием магматических расплавов, питающих вулканы. Полученные результаты свидетельствуют об общности глубинных структур Южной Камчатки и Курильской островной дуги, а также о различии в глубинном строении Северной и Южной Камчатки, разделенных зоной разломов, возможно, проникающих в верхнюю мантию. Предполагается, что выявленные особенности в строении Южной Камчатки обусловлены глубинными процессами со стороны не только Тихого океана, но и южных окраин Охотского моря. Полученные результаты представляют интерес для геодинамики, вулканологии, тектоники и других наук о Земле.
\end{abstract}

Ключевые слова: сейсмология; сейсмотомография; геоэлектрика; скорость сейсмических волн; электропроводность; землетрясение; вулкан; гидротермальный раствор; магматический расплав

\section{1. ВВЕДЕНИЕ}

Курило-Камчатская островная дуга (ОД) относится к переходной зоне материк - океан в северозападной (С3) части Тихого океана (рис. 1). Этот регион характеризуется высоким уровнем сейсмичности, вулканической и гидротермальной деятельности, который связан с активными геодинамическими процессами, протекающими в литосфере и в более глубокой мантии. Большой научный интерес представляет п-ов Камчатка, являющийся северной частью Курило-Камчатской островной дуги. Северная часть полуострова расположена в области пересечения с Алеутской островной дугой; со стороны Тихого океана к ней максимально приближены Императорские горы и Императорский разлом (рис. 1). На пересечении этих структур в северной части полуострова сформировался крупнейший вулканический центр Евразии - Ключев- ская группа вулканов. Южная Камчатка находится под влиянием структур северной части Курильской островной дуги, Охотского моря, а также разломов литосферы северо-западного простирания акватории Тихого океана. Данные факторы определяют сложную глубинную структуру Камчатского полуострова. Строение земной коры и мантии на юге и севере, вероятно, имеет существенные различия, связанные с геологической историей развития Камчатки.

В последние годы созданы глубинные сейсмотомографические модели Курило-Камчатского региона и его окружения, характеризующие распределение скоростных неоднородностей среды. На их базе для Камчатки рассмотрен ряд скоростных моделей, позволяющий выявить связь скоростных свойств коры и верхней мантии с сейсмичностью и глубинными разломами. Наряду с этим имеются данные глубинной геоэлектрики, магнитометрии, 


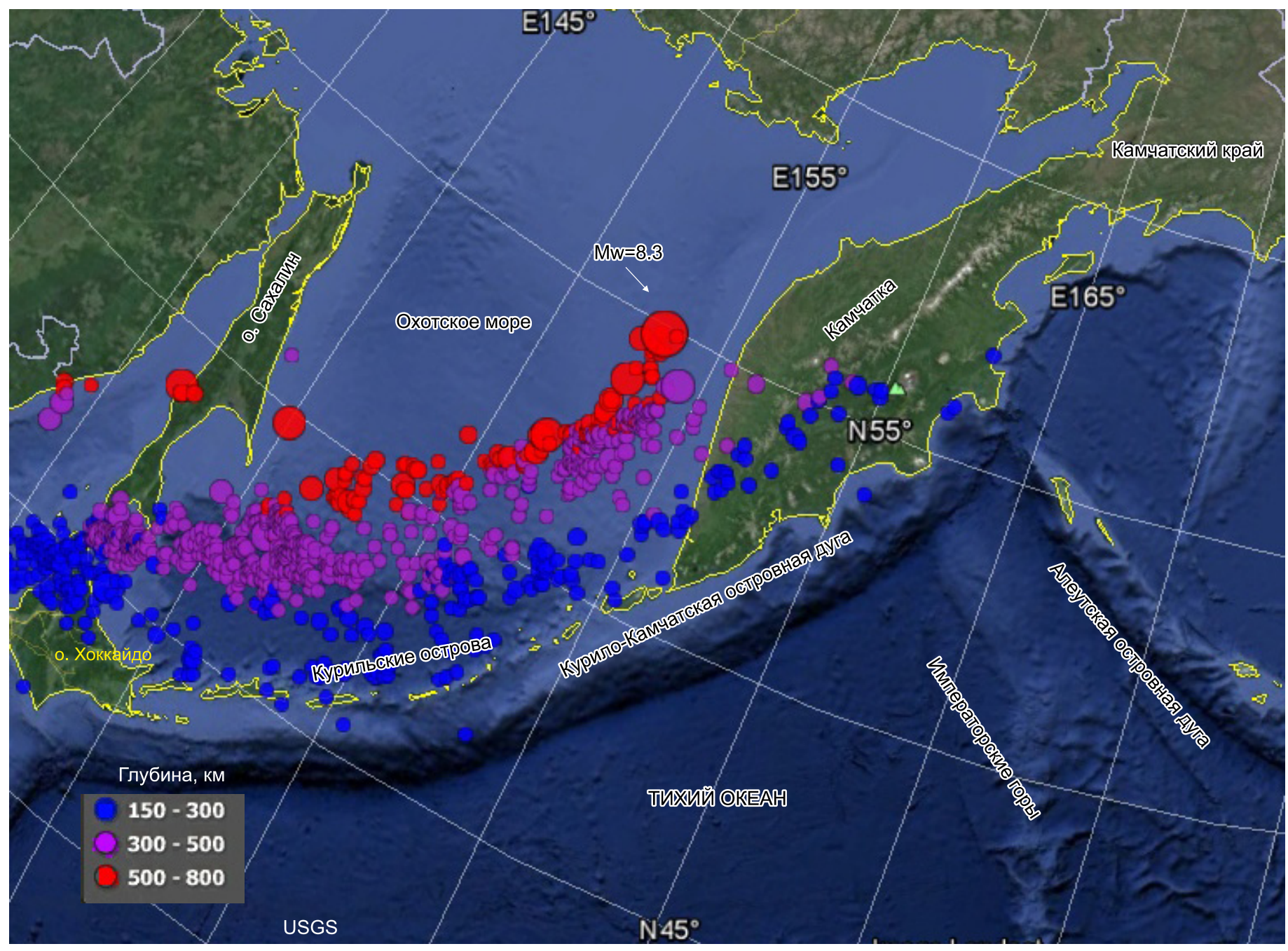

Pис. 1. Сейсмичность мантии на глубинах 150-800 км. Гипоцентры землетрясений взяты из каталога USGS (United States Geological Survey).

Fig. 1. Seismicity of the mantle at depths of 150-800 km. Earthquake hypocenters from the United States Geological Survey (USGS) Catalogue.

гравиметрии, сведения о тектонике и магматизме. Анализ геолого-геофизической информации дает возможность определить основные особенности глубинного строения Камчатки и области ее сочленения с Курильскими островами. Решению этой задачи посвящена настоящая статья.

\section{2. СКОРОСТНАЯ НЕОДНОРОДНОСТЬ МАНТИИ РЕГИОНА (ГЛОБАЛЬНЫЕ ДАННЫЕ)}

Представление о скоростной характеристике мантии Камчатки, Курильских островов и сопредельных районов дает глобальная сейсмотомографическая модель востока России, разработанная до глубины 3000 км [Zhao et al., 2010]. Она характеризует изменение наиболее общих особенностей скоростной структуры вдоль Курило-Камчатской ОД (рис. 2). Оценка значений аномалий скорости продольных Р-волн выполнена относительно глобальной модели IASP91. Диапазон аномалий составляет от $-1 \%$ (красный цвет) до +2 \% (синий цвет), т. е. контраст скоростей Р-волн незначителен. Вероятно, столь малые значения аномалий связаны с сильным сглаживанием моделей из-за отсутствия сейсмостанций на большей части исследуемой территории. На скоростных изображениях вдоль ОД, с севера на юг, четко выражено различие скоростных свойств верхней мантии в акваториях Тихого океана и Охотского моря, т. е. по обе стороны Камчатки и Курил. Можно отметить увеличение мощности высокоскоростной тихоокеанской аномалии (литосферы), а также изменение скоростных свойств «подлитосферной» верхней мантии. Под Охотским морем литосфера характеризуется относительно пониженными значениями аномалий скорости. 

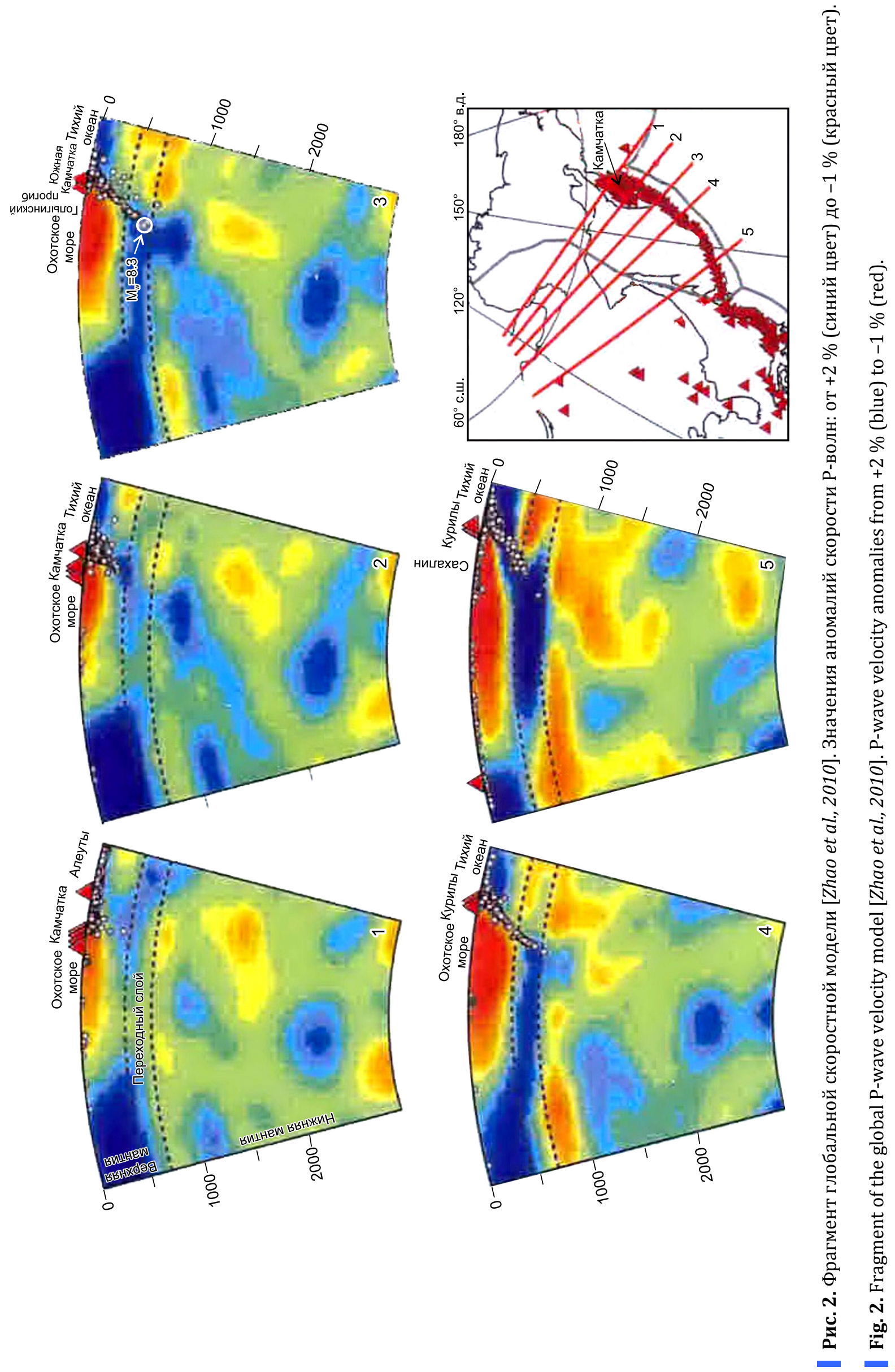
При этом на юге Камчатки и вдоль Курил она в целом более низкоскоростная и, следовательно, разуплотнена по сравнению с северной частью полуострова.

Характер зоны перехода «верхняя - нижняя мантия» также заметно изменяется (рис. 2). В северной части Камчатки переходная зона практически не отличается от одномерной глобальной модели IASP91, а в южном направлении четко проявляются скоростные контрасты. Примечательно, что по сравнению с Южной Камчаткой и Курилами верхняя мантия в северной части Камчатки менее контрастна на модели скоростных аномалий, что, вероятно, говорит о разных термодинамических условиях протекающих глубинных процессов. Фокальный слой в скоростном поле на севере Камчатки выражен слабо и просматривается только в литосфере. На юге полуострова и Курилах картина иная. Фокальный слой в этих регионах выделяется непрерывно вдоль всей мощности верхней мантии, достигая зоны перехода к нижней.

Более детальное представление о распределении скоростных неоднородностей в мантии Курило-Камчатского региона (до глубины 1100 км) и п-ва Камчатка (до 700 км) дают работы [Koulakov et al., 2011; Zhao et al., 2010]. Результаты региональной томографии, представленные в них, получены на основе данных глобальных сейсмологических каталогов. Скоростные модели демонстрируют в общем близкие скоростные свойства мантии в изученных интервалах глубин. Это, вероятно, говорит о схожести авторских подходов при инверсной томографии на объемных волнах. Различия в рисунке аномалий скорости, их интенсивности могут быть связаны с разными конфигурациями используемых авторами сетей наблюдений и выборками землетрясений, исходными скоростными моделями. Так, в работе [Zhao et al., 2010] принята референтная скоростная модель IASP91 [Kennett, Engdahl, 1991], в работе [Koulakov et al., 2011] - AK135 [Kennett et al., 1995]. Принимая во внимание то, что на Камчатке была использована более равномерная сеть станций и структура верхней мантии проявлена в более контрастном рисунке скоростных аномалий Рволн, в частности в пределах фокального слоя, остановимся на результатах работы [Zhao et al., 2010]. Вертикальные сечения объемной скоростной модели показаны на рис. 3. На разрезах нами приведены гипоцентры землетрясений с Ks=9.5-17.0 из регионального каталога данных Камчатского филиала Единой геофизической службы (КФ ЕГС) РАН. Рисунок аномалий скорости в структуре фокального слоя и соответствующая выявленным аномалиям картина сейсмичности изменяются по простиранию полуострова. Наиболее ярко в скоростном поле фокального слоя проявляется высо- коскоростная аномалия, соответствующая литосферному блоку верхней мантии.

Эта аномалия выделяется до глубины 200250 км и менее в северной части полуострова. Глубже этого блока, в интервале 100-150 км, просматривается зона, в которой отсутствует высокоскоростной фокальный слой. Происходящие здесь, как правило, слабые землетрясения могут быть «откликом» на более сильные события в вышележащей литосфере. Возможно, они связаны с какими-то процессами преобразования (к примеру, полиморфными) вещества мантии. Отметим, что «литосферной» части фокального слоя соответствует более высокий уровень сейсмичности и в среднем относительно повышенные значения скорости Р-волн. Яркие латеральные контрасты в распределении скоростных аномалий просматриваются также в глубинных частях разреза (рис. 3). Так, под прибрежным районом Южной Камчатки, со стороны Охотского моря, в верхней мантии и переходном слое (в интервале глубин 400-600 км) выделяется блок с положительными значениями аномалий скорости. Ему соответствует повышенный уровень сейсмичности (разрезы АА и BB) (рис. 3). В 2013 г. здесь произошло Охотоморское глубокофокусное землетрясение с магнитудой 8.3. В северной части Камчатки высокоскоростная аномалия на таких глубинах отсутствует. Она прослеживается на ЮЗ полуострова и протягивается вдоль Курильской гряды [Koulakov et al., 2011]. Мантийным аномалиям повышенной скорости соответствует полоса глубокофокусной сейсмичности (см. рис. 1). В геологическом плане эти аномалии скорости и сейсмичности приурочены к краевым впадинам южной и юго-восточной части Охотского моря.

\section{3. СКОРОСТНЫЕ НЕОДНОРОДНОСТИ ЛИТОСФЕРЫ КАМЧАТКИ (РЕГИОНАЛЬНЫЕ ДАННЫЕ)}

По данным о местных землетрясениях, взятым из регионального каталога КФ ЕГС РАН, рассчитана скоростная модель литосферы п-ва Камчатка [Gontovaya et al., 2003, 2010; Gorbatov et al., 1999; Nizkous et al., 2007]. Региональные модели позволяют получить более детальные представления о скоростной структуре литосферы и сопоставить ее с другими геолого-геофизическими данными.

Для Камчатки, в силу особенности расположения источников и приемников, моделирование глубинного строения с высокой точностью можно проводить только для восточной части полуострова. Оценки разрешающей способности показали, что начиная с глубины 20 км область хорошего разрешения не имеет разрывов и занимает максимальную площадь. Наилучшая разрешенность 
(a)
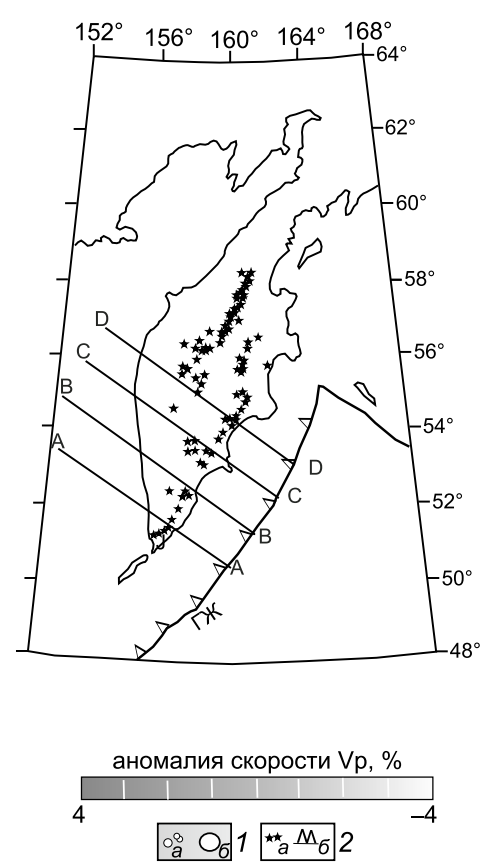

(б)

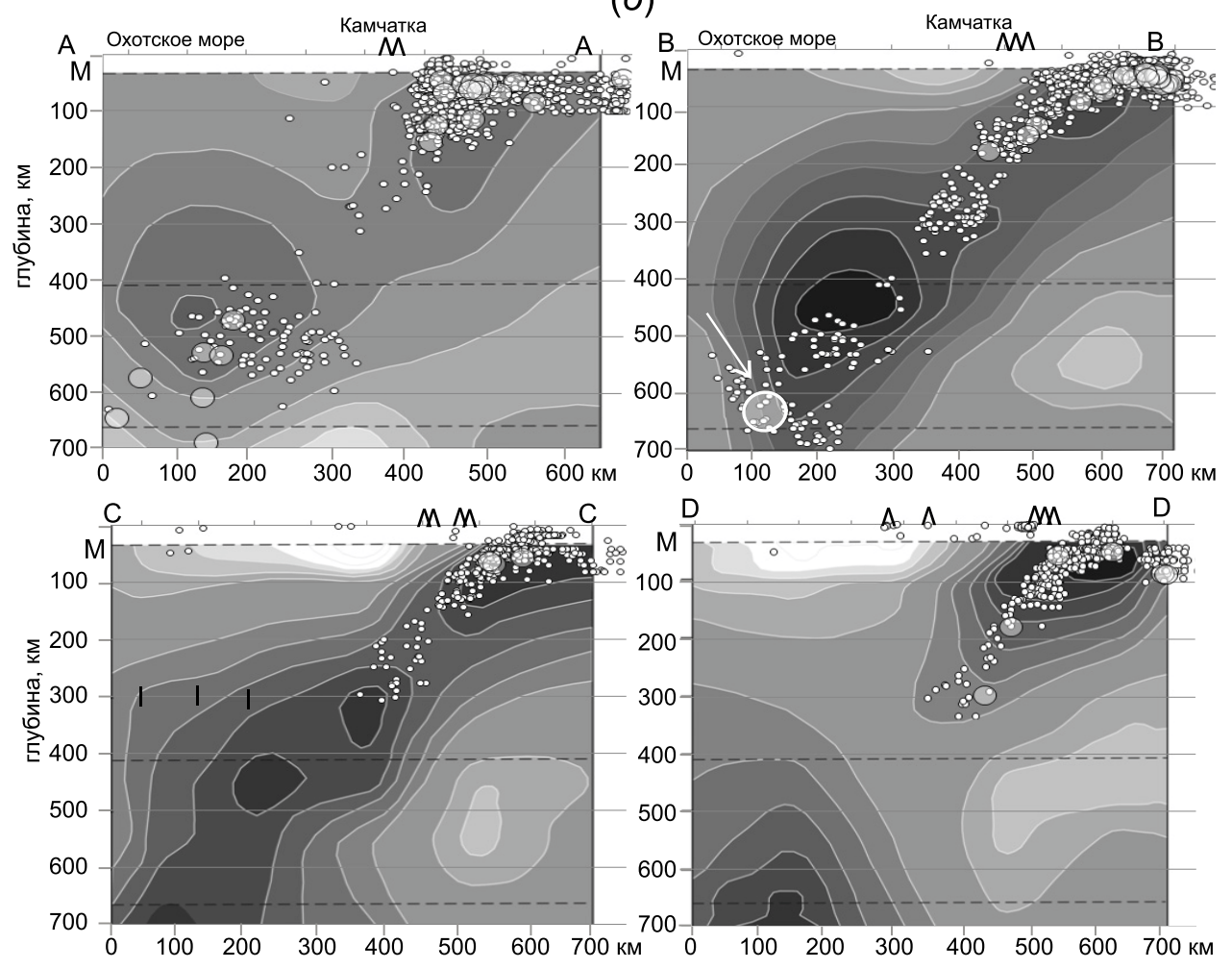

Рис. 3. Скоростные неоднородности и гипоцентры землетрясений в верхней мантии в районе Камчатки. Фрагменты скоростной модели взяты из работы [Jiang et al., 2009]. 1 - гипоцентры землетрясений с К: 8.5-12.5 (a), 12.6-16 (б); 2 - вулканы на схеме (a) и разрезах (б).

Fig. 3. P-wave velocity inhomogeneities and earthquake hypocenters in the upper mantle of Kamchatka. Fragments of the Pwave velocity model from [Jiang et al., 2009]. 1 - earthquake hypocenters, Ks: 8.5-12.5 (a), $12.6-16$ (б); 2 - volcanoes in Fig. 3 (a) and Fig. 3 (б).

достигается в диапазоне глубин 40-100 км. Глубже 120 км эта область уменьшается в размерах и смещается на запад в сторону Центрально-Камчатской депрессии. Полученные результаты представлены в виде горизонтальных (рис. 4) и вертикального (рис. 5) сечений объемной модели распределения аномалий скорости Р-волн. Исходная одномерная скоростная модель литосферы полуострова рассчитана по данным регионального каталога землетрясений КФ ЕГС РАН. Она отличается большей детальностью разреза земной коры и верхней мантии по сравнению с используемой при расчете координат гипоцентров камчатских землетрясений [ $\mathrm{Niz}-$ kous et al., 2006].

Томографическая модель свидетельствует о вертикальной и латеральной неоднородности литосферы в зоне перехода «океан - континент». Неоднороден по скоростным характеристикам также и фокальный слой, который в глобальных моделях охарактеризован в целом положительными аномалиями; неоднороден и мантийный клин - относительно низкоскоростной. В скоростном поле литосферы Восточной Камчатки в интервале глубин
40-80 км четко выделяется слой относительно повышенной скорости (рис. 5), который глубже 7080 км подстилается слоем пониженных скоростей астеносферным слоем мантийной литосферы.

Существование данного слоя и его взаимосвязь с магмопитанием вулканов Восточно-Камчатского вулканического пояса (ВКВП) подтверждаются расчетами тепловой модели и на ее основе - скоростной модели [Gontovaya, Gordienko, 2006, 2009].

Вулканический пояс проецируется на низкоскоростной слой и область высоких скоростных градиентов в основании СФЗ (см. рис. 4, рис. 5). На горизонтальных сечениях объемной модели (на глубинах 80-120 км) данный слой хорошо выражен в виде полосы отрицательной аномалии скорости. Она имеет продолжение в северном направлении до области пересечения островных дуг (см. рис. 4). Вторая полоса низкоскоростных аномалий протягивается вдоль Центрально-Камчатского прогиба (ЦКП) (на глубинах 120-160 км)и, в свою очередь, имеет продолжение в южном направлении до границы сочленения Южной и Северной Камчатки. 


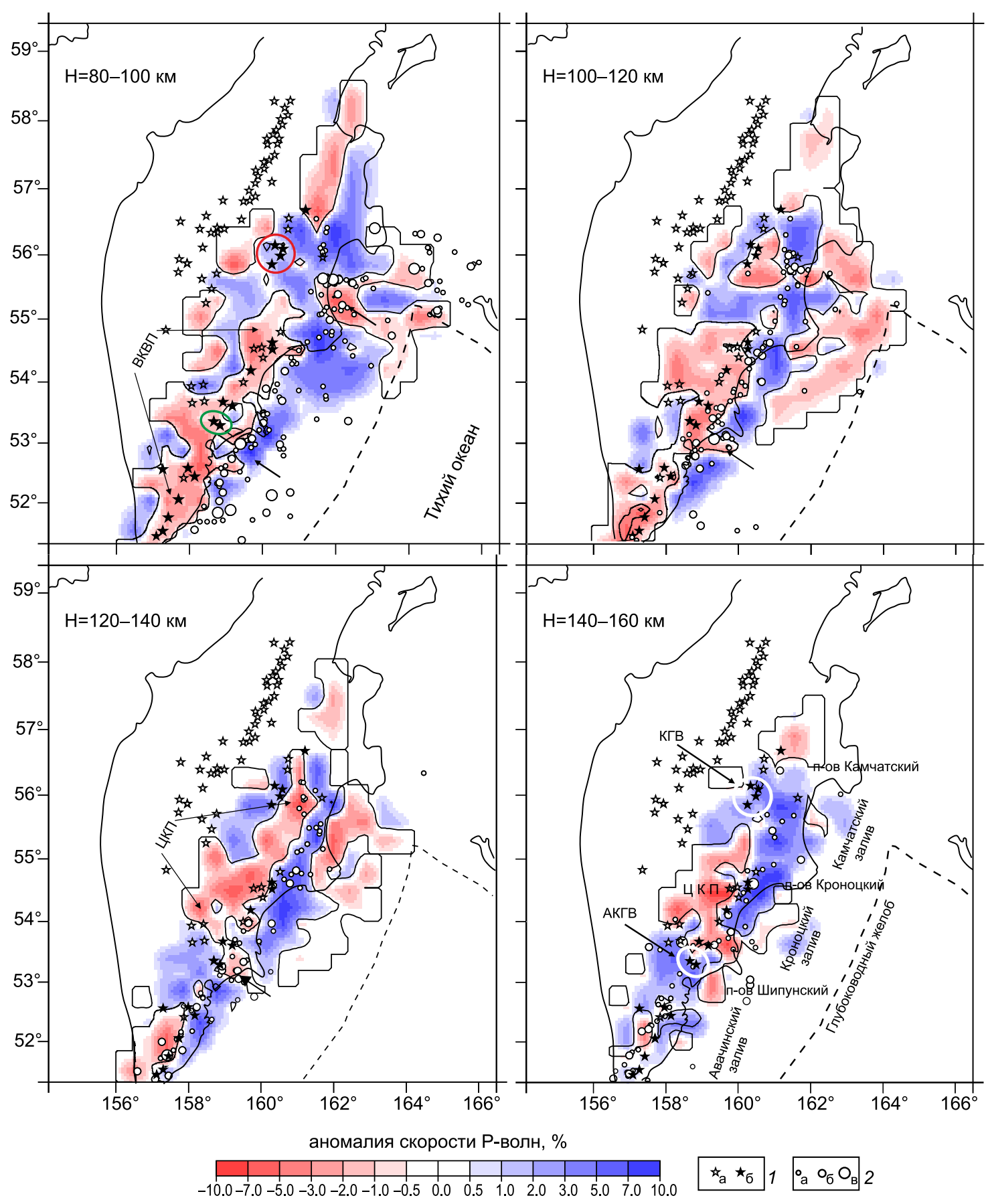

Рис. 4. Горизонтальные сечения региональной 3-D скоростной модели литосферы Восточной Камчатки в интервалах глубин 80-100, 100-120, 120-140 и 140-160 км. 1 - вулканы: потухшие (а), активные (б); 2 - эпицентры землетрясений с Ks: 10-11 (а), 11-13 (б), >13 (в).

Fig. 4. Horizontal cross-sections of the regional 3D P-wave velocity model of the East Kamchatka lithosphere at the depths of 80-100, 100-120,120-140, and 140-160 km. 1 - volcanoes: extinct (a), active (б); 2 - earthquake epicenters, Ks: 10-11 (а), 11-13 (б), >13 (в).

Одним из важных элементов рассматриваемого варианта региональной модели следует считать проявление в верхней мантии аномальных свойств, вероятно, свидетельствующих о присутствии в разломных зонах мантийного заложения. Здесь мы обращаем внимание на аномалию фокального слоя в районе Авачинско-Жупановских вулканов, где на глубине $\sim 140$ км в 2017 г. произошло сильное Жупановское землетрясение с $\mathrm{Mw}=7.1$ (рис. 5). На горизонтальных срезах (120-140 км) разломная зона проявляется в виде поперечной отрицательной аномалии, которая начинается в Авачин- 


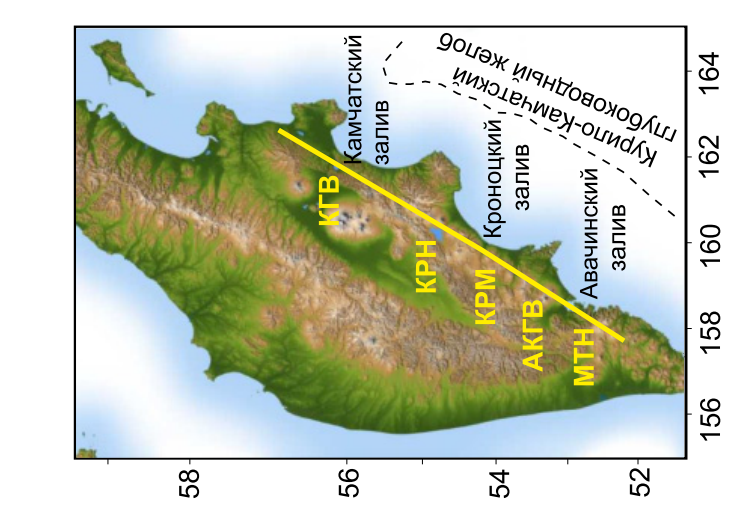

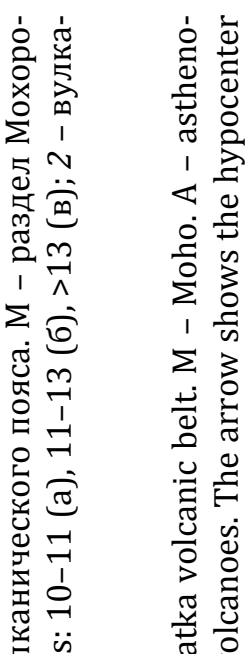

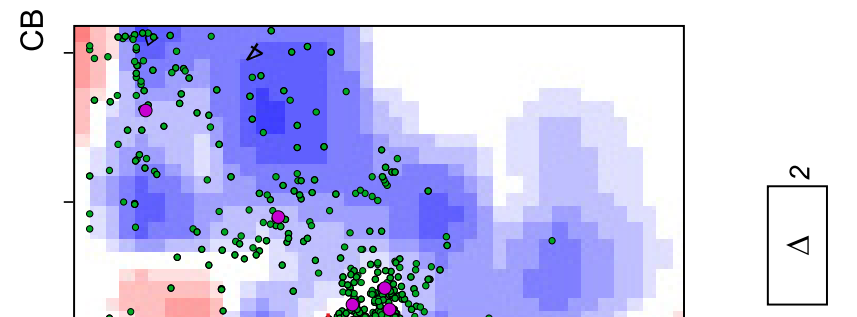

究

步

要离 芯

㫐蒙

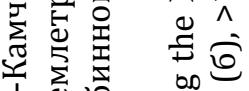

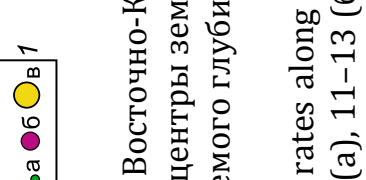

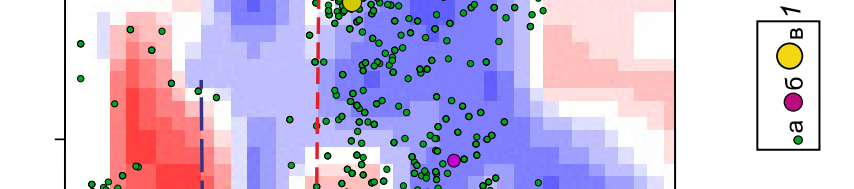

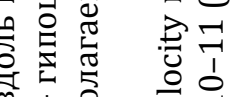

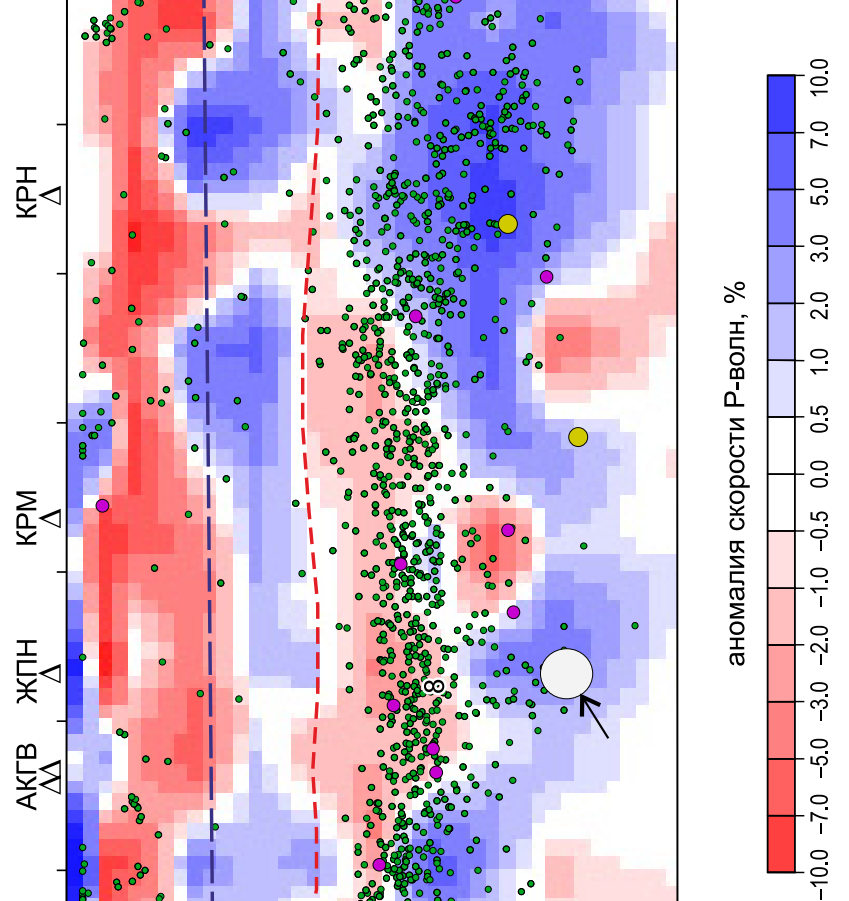

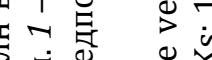

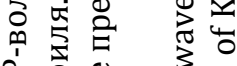

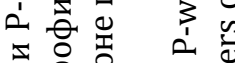

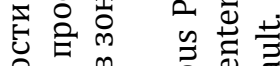

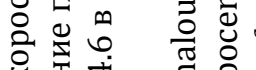

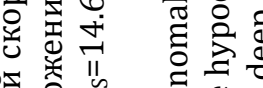

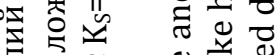

䆑宫

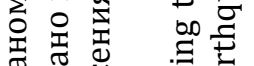

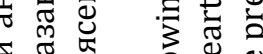

उ 50

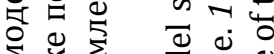

mे

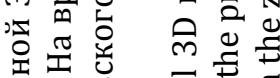

峦

表苛

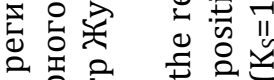

范

声苨

U.

준

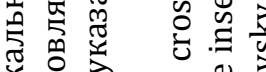

可 害

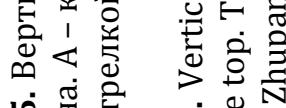

ம்

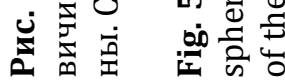




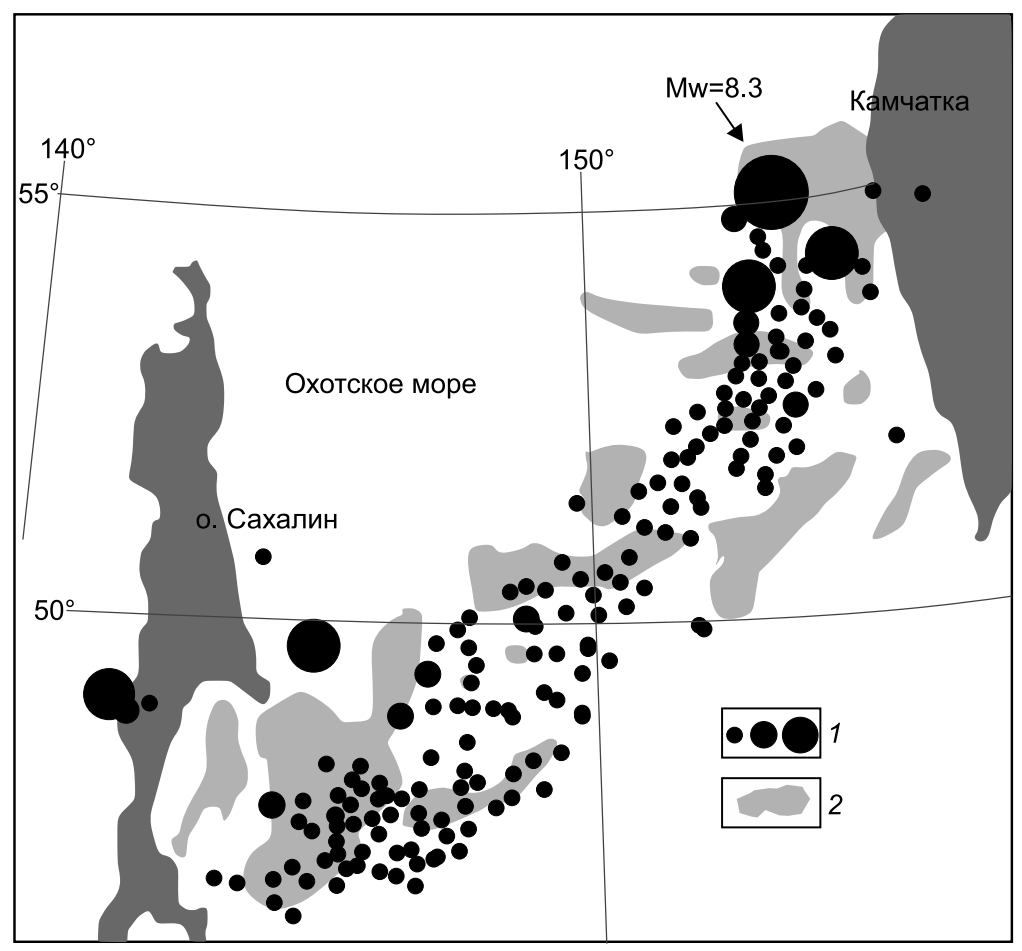

Рис. 6. Зона глубокой сейсмичности и геологические структуры в южной части Охотского моря. 1 - эпицентры землетрясений на глубинах 400700 км; 2 - районы с мощностью молодых осадков $3 \pm 1$ км и глубиной дна $1 \pm 0.3$ км. Стрелкой указан эпицентр сильнейшего Охотоморского землетрясения.

Fig. 6. Deep seismicity zone and geological structures in the southern part of the Sea of Okhotsk. 1 - earthquake epicenters at depths of 400-700 km; 2 - areas with young sedimentation $(3 \pm 1 \mathrm{~km}$ thick) and the bottom depth of $1 \pm 0.3 \mathrm{~km}$. The arrow shows the epicenter of the strongest Okhotsk Sea earthquake. ском заливе и продолжается в СЗ направлении на сушу.

Наряду с выявленной клинообразной скоростной неоднородностью в мантии отмечается скоростная неоднородность фокального слоя. При этом зонам скоростных градиентов в данном слое соответствуют зоны повышенного уровня сейсмичности и изменение общей геометрии слоя (рис. 5).

\section{4. ОСОБЕННОСТИ ГЛУБИННОГО СТРОЕНИЯ КАМЧАТКИ}

Анализ распределения скоростных неоднородностей и сейсмичности в литосфере и более глубокой мантии Камчатки свидетельствует, что они значительно отличаются по простиранию полуострова. Территория Северной Камчатки находится в области влияния геодинамических процессов со стороны Алеутской островной дуги. Отражением этих процессов являются поперечные глубинные разломы, к которым приурочены крупнейшие вулканы Ключевской группы [Moroz, Gontovaya, 2017]. Южная Камчатка во многом сходна с Северными Курилами, оба региона приурочены к единой зоне глубокофокусных землетрясений в низах верхней мантии и переходном слое на глубинах 400-700 км (рис. 6).

Отмечается связь структур Курильской островной дуги и юга полуострова. Так, Курильская глубоководная котловина в южной части Охотского моря (рис. 7) имеет продолжение на Южной Кам- чатке в виде Голыгинского прогиба [Grannik, 2008; Gnibidenko, 1979]. Он, как и котловина, заполнен мощной осадочно-вулканогенной толщей. O современных активных процессах в пределах Курильской котловины говорят высокие значения теплового потока, достигающие 300 мВт/м² [Sergeev, Krasny, 1987]. Они повышены также в пределах северо-восточного (CB) продолжения впадины (здесь - до 100 мВт/м²). Это свидетельствует о продолжении тектонической активности и в районе Голыгинского прогиба. На территорию Южной Камчатки продолжается и зона современной активности, по существу единая для Курило-Камчатской островной дуги. На полуострове она протягивается в виде ВКВП до зоны влияния Алеутской островной дуги. Особенности магматизма активных вулканов в этой зоне, вероятно, взаимосвязаны с выявленным в скоростной модели литосферы астеносферным слоем на глубине 70-120 км.

Анализ геофизической и геологической информации свидетельствует о различном строении земной коры и верхней мантии Северной и Южной Камчатки. При этом важно отметить, что на юге полуострова, как и на Северных Курилах, неогеновый, палеогеновый и четвертичный вулканизм выражен в единой вулканической зоне. На Северной Камчатке существуют две или три вулканические зоны, различные по своему возрасту; расстояние между ними составляет не менее 100 км (рис. 7).

В геомагнитном поле Южная Камчатка характеризуется сочетанием линейных положительных и 


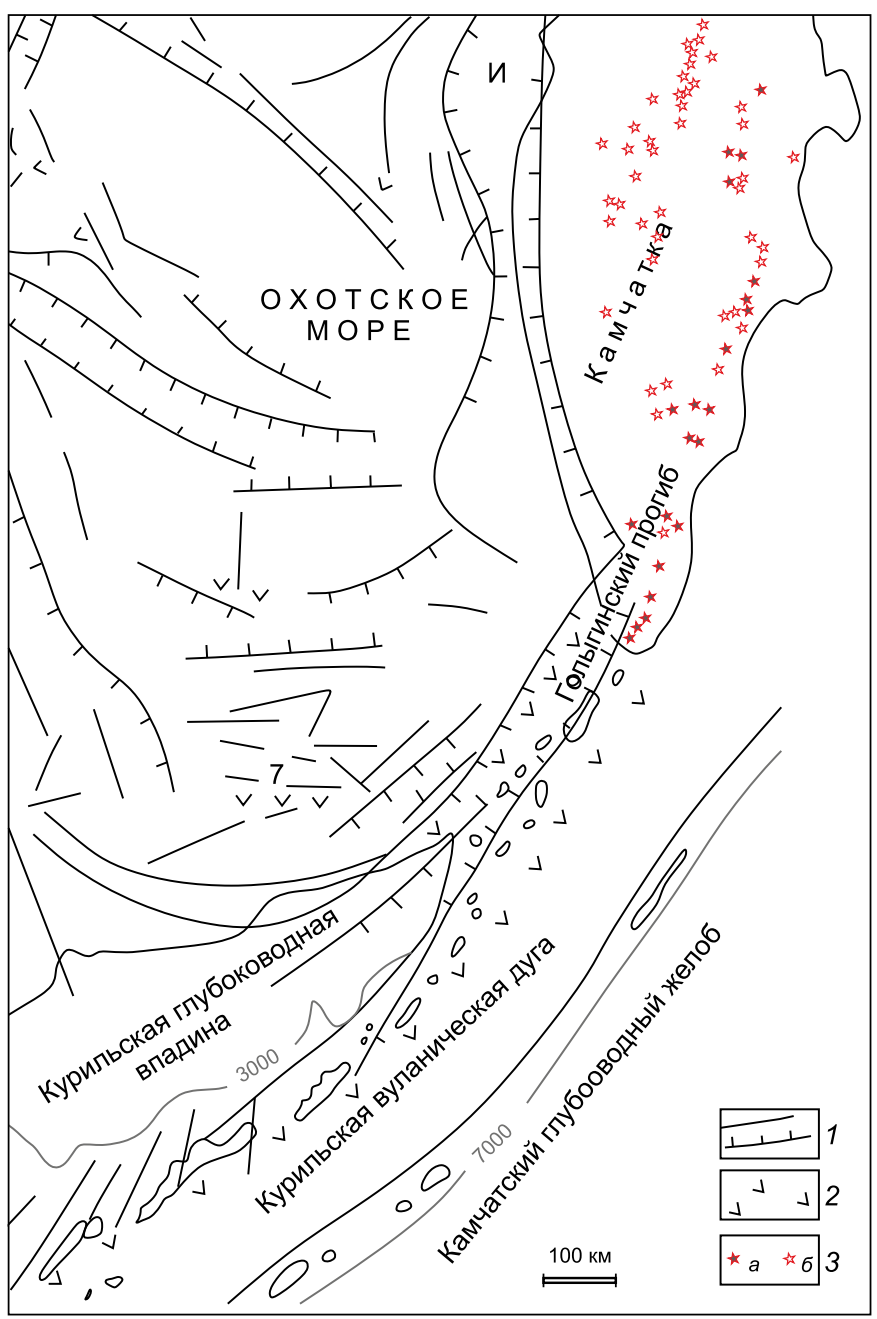

отрицательных аномалий северо-западного простирания, имеющих продолжение в акватории Тихого океана. Данные аномалии отражают разломные структуры, ориентированные поперек простирания полуострова. В связи с этим существует представление, что структуры подстилающего основания являются поперечными по отношению к простиранию молодых (четвертичных) сооружений юга Камчатки [Sidorenko, 1964].

Возникает вопрос о границе между структурами Южной и Северной Камчатки. Такой структурой, по-видимому, является Петропавловск-Малкинская зона поперечных дислокаций [Sidorenko, 1964; Litvinov et al., 1999]. На геологической карте, обобщающей геолого-геофизические исследования, выделены глубинные разломы, пересекающие Южную Камчатку в поперечном направлении (рис. 8). Отмечается их продолжение в акватории Авачинского залива [Popruzhenko, Zubin, 1997].

Протяженность разломов на суше составляет не менее 200 км; по всей видимости, они являются продолжением глубинных разломов акватории Тихого океана, которые достигают глубины около 70 км и, вероятно, имеют природу трансформной
Рис. 7. Фрагменты тектонической схемы кайнозойских структурных элементов Охотского моря [Grannik, 2008] с дополнением вулканических зон Камчатки. 1 - рифтовые структуры; 2 - вулканический пояс; 3 - вулканы активные (а), потухшие (б).

Fig. 7. Fragments of the tectonic schematic map showing the Cenozoic structural elements of the Sea of Okhotsk [Grannik, 2008] and volcanic zones of Kamchatka. 1 - rift structures; 2 - volcanic belt; 3 - active (a) and extinct (б) volcanoes. разломной зоны [Seliverstov, 2009]. ПетропавловскМалкинская зона поперечных дислокаций включает крупнейшую Авачинско-Корякскую группу современных вулканов, также вытянутую в северозападном направлении. Глубинное строение зоны изучено методом магнитотеллурического зондирования по профилю, проходящему между Авачинским и Корякским вулканами (рис. 9).

Под Авачинско-Корякской группой вулканов хорошо выражен осадочно-вулканогенный слой с пониженным удельным электрическим сопротивлением до 5-10 Ом•м на глубинах от первых сотен метров до 2-5 км. Максимальная мощность отмечается в Авачинском грабене, расположенном к западу от вулканических сооружений Авачинского и Корякского вулканов. Глубинная часть модели содержит субвертикальные проводящие зоны с удельным электрическим сопротивлением от первых единиц до 10 Ом•м. Аномальная зона повышенной электропроводности (МТ3 7-11) сопряжена в верхней части с Авачинским грабеном. Она распространяется до глубины примерно 30 км. Ширина аномалии на глубине 20 км составляет около 4-5 км. В нижней своей части она уменьша- 


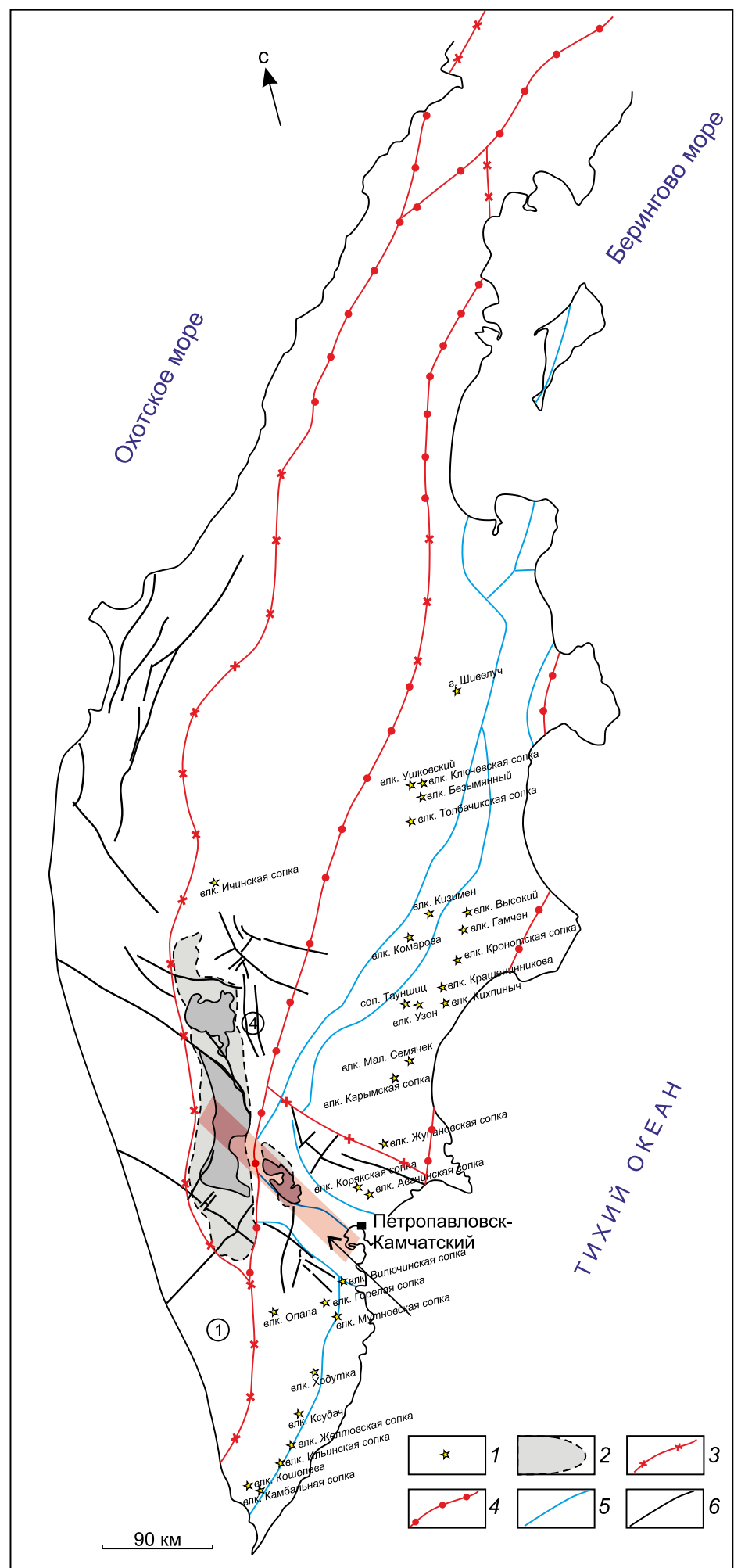

ется до 2-3 км. Вторая аномальная зона повышенной электропроводности выделяется на глубинах от 10 до 40 км с удельным электрическим сопротивлением от первых единиц до 10 Ом·м. По узкому проводящему каналу она соединена с осадочновулканогенным чехлом. В юго-западной части профиля на глубинах 15-25 км выражен слой повышенной электропроводности, сопряженный с суб-
Рис. 8. Схема глубинных разломов Камчатки (фрагмент [Litvinov et al., 1999]).

1 - вулканы; 2 - породы Срединного массива; 3 - глубинные разломы по геофизическим данным; 4 - глубинные разломы по геологическим данным; 5-6 - прочие тектонические границы. Стрелкой показана Петропавловск-Малкинская зона поперечных дислокаций.

Fig. 8. Schematic map of deep faults in Kamchatka (fragment from [Litvinov et al., 1999]).

1 - volcanoes; 2 - rocks of the Middle massif; 3 - deep faults according to geophysical data; 4 - deep faults according to geological data; 5-6 - other tectonic boundaries. The arrow shows the Petropavlovsk-Malkinsky zone of transverse dislocations. вертикальной проводящей глубинной зоной. Это согласуется с полученными нами ранее результатами [Moroz, Gontovaya, 2003].

Выявленные субвертикальные зоны повышенной электропроводности связываются с глубинными разломами северо-западного простирания. Разломы имеют, по-видимому, значительную протяженность и пересекают южную часть Камчатки 

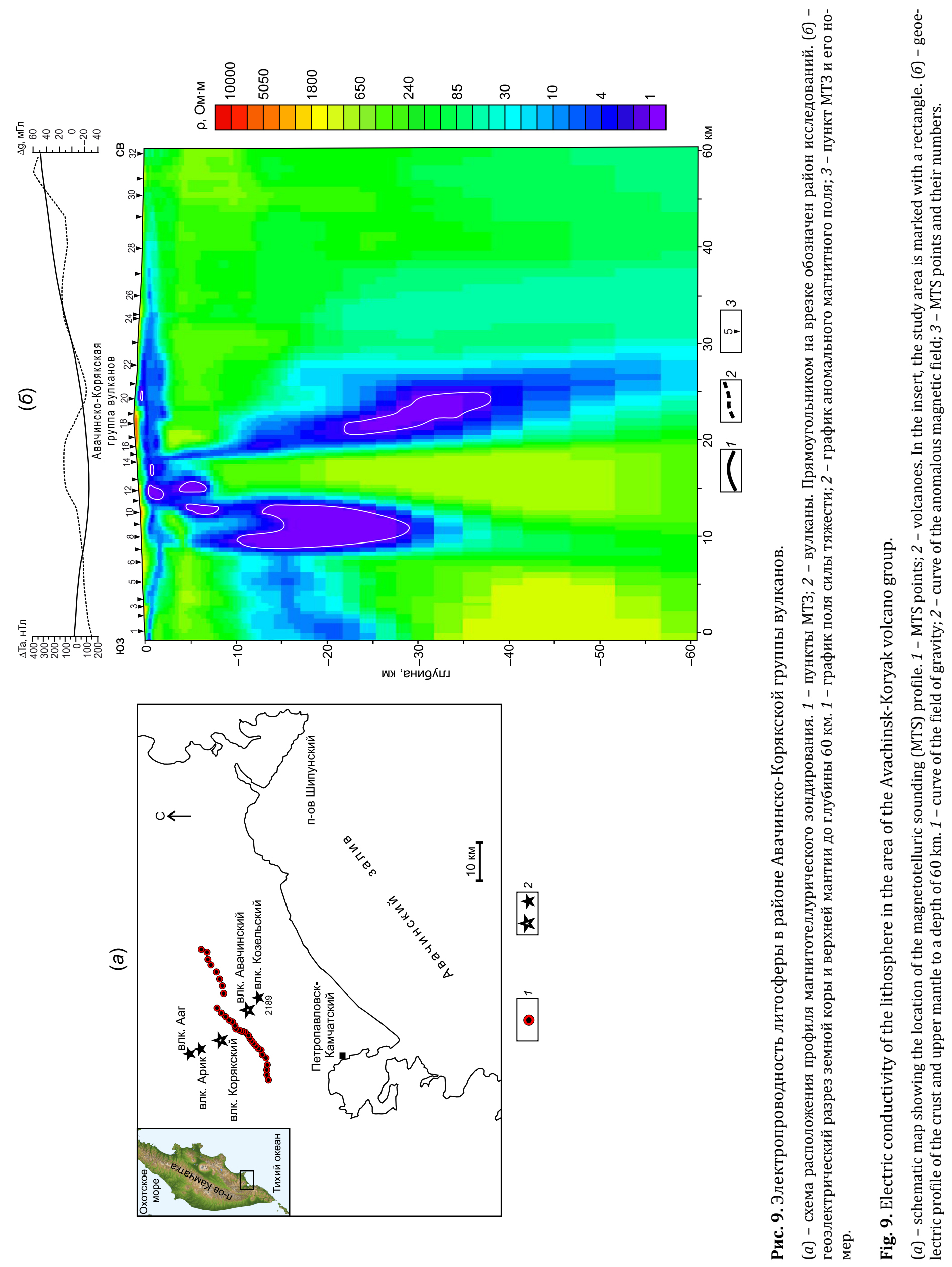
от Авачинского залива до Охотского моря. Проводящие глубинные разломы, по-видимому, содержат жидкие флюиды в виде гидротермальных растворов и магматических расплавов. Частичное плавление пород в зоне разломов может быть связано с поступлениями растворов из корового слоя и просачиваний вадозных, которые существенно понижают температуру плавления пород литосферы. Жидкие флюиды из глубинных разломов проникают в верхние части земной коры и питают современные вулканы.

\section{5. ЗАКЛЮЧЕНИЕ}

По результатам сейсмологического и геоэлектрического моделирования, а также по другим геофизическим и геологическим данным определены особенности структуры земной коры и верхней мантии северной части Курило-Камчатской островной дуги. Представление о строении мантии региона получено по сейсмотомографическим изображениям скоростных моделей, построенным по продольным волнам от удаленных землетрясений до глубин 2000 и 700 км. Скоростная модель до глубины 700 км сопоставлена с особенностями распределения гипоцентров землетрясений по данным из регионального каталога КФ ЕГС РАН. Анализ сейсмотомографических моделей свидетельствует о значительных неоднородностях структуры верхней мантии по простиранию полуострова. На юге отмечены две контрастные высокоскоростные зоны, разделенные значительными (более 100 км) интервалами относительно пониженной скорости и сейсмического молчания. Верхняя высокоскоростная зона до глубин 200-250 км хорошо выражена в районе Восточной Камчатки до пересечения с Алеутской островной дугой. Нижняя высокоскоростная зона глубже 300-400 км приурочена к прибрежным районам Южной Камчатки со стороны Охотского моря. Эта зона вытянута в югозападном направлении в сторону Курильских островов. В северо-восточном направлении (за пределами района Южной Камчатки) зона глубокофокусных землетрясений отсутствует.

По данным о региональных землетрясениях, зарегистрированных камчатской сетью станций КФ ЕГС РАН, разработана скоростная модель литосферы Камчатки с более высоким, чем в предшествующих моделях, разрешением. Она существенно дополняет и уточняет сейсмотомографические модели по телесейсмическим данным и позволяет составить представление об особенностях глубинного строения земной коры и верхней мантии до глубины около 200 км. Анализ показал, что аномалии скоростных параметров и распределение гипоцен- тров землетрясений в коре и мантии Южной Камчатки в большей мере сопоставимы с глубинной моделью района Северных Курил, чем Северной Камчатки. Существование зоны глубокофокусных землетрясений в районах Курильских островов и Южной Камчатки, а также особенности скоростной структуры литосферы и глубокой мантии показывают, что юг Камчатки, как и Северные Курилы, находится под влиянием схожих тектонических процессов.

Граница между структурами Южной и Северной Камчатки связывается с зоной поперечных глубинных разломов, пересекающих Южную Камчатку. Они выражены в современном тектоническом плане в виде Петропавловск-Малкинской зоны поперечных дислокаций. Зона разломов имеет продолжение в акваторию Авачинского залива Тихого океана. На сейсмотомографическом разрезе данная зона приурочена к высокому градиенту изменения глубины залегания подошвы астеносферного слоя, выявленного по отрицательным аномалиям скорости в его пределах.

Петропавловск-Малкинская зона поперечных дислокаций включает Авачинско-Корякскую зону современного вулканизма. Строение вулканической зоны изучено методом магнитотеллурического зондирования. Глубинная часть магнитотеллурической модели содержит субвертикальные проводящие зоны с удельным электрическим сопротивлением от первых единиц до 10 Ом•м. Они связываются с глубинными разломами северо-западного простирания. Проводящие глубинные разломы, по-видимому, содержат жидкие флюиды в виде гидротермальных растворов и жидких легкоподвижных компонентов магмы, питающих современные вулканы.

Таким образом, приведенная информация свидетельствует об общности глубинных структур районов Южной Камчатки и Курильской островной дуги и различии в глубинном строении Северной и Южной Камчатки, разделенных зоной разломов, проникающих в верхнюю мантию. Предполагается, что выявленные особенности в строении Южной Камчатки обусловлены геодинамическими процессами не только со стороны Тихого океана, но и со стороны южных окраин Охотского моря, что выражено зоной глубинной сейсмичности, приуроченной к глубоководному прогибу и впадинам моря с повышенным тепловым потоком.

\section{6. БЛАГОДАРНОСТИ}

Работа выполнена при поддержке РФФИ (проект № 16-05-00059). 


\section{7. ЛИТЕРАTУРA / REFERENCES}

Gnibidenko G.S., 1979. Tectonics of the Marginal Seas of the Far East. Nauka, Moscow, 163 p. (in Russian) [Гнибиденко Г.С. Тектоника окраинных морей Дальнего Востока. М.: Наука, 1979. 163 с.].

Gontovaya L.I., Gordienko V.V., 2006. Deep processes, seismological and thermal models of East Kamchatka. Geology and Minerals of the World Ocean (2), 107-121 (in Russian) [Гонтовая Л.И., Гордиенко В.В. Глубинные процессы, сейсмологическая и тепловая модели Восточной Камчатки // Геология и полезные ископаемые Мирового океана. 2006. № 2. С. 107-121].

Gontovaya L.I., Gordienko V.V., 2009. Density model of the tectonosphere of the transition zone in Kamchatka. Geology and Minerals of the World Ocean (3), 58-69 (in Russian) [Гонтовая Л.И. Гордиенко В.В. Плотностная модель тектоносферы переходной зоны в районе Камчатки // Геология и полезные ископаемые Мирового океана. 2009. № 3. C. 58-69].

Gontovaya L.I., Levin V.I., Sanina I.A., Senyukov S.L., Stepanova M.A., 2003. Velocity inhomogeneities of the lithosphere under Kamchatka. Vulkanologiya i Seismologiya (Journal of Volcanology and Seismology) (4), 56-64 (in Russian) [Гонтовая Л.И., Левина В.И., Санина И.А., Сенюков С.Л., Степанова М.А. Скоростные неоднородности литосферы под Камчаткой // Вулканология и сейсмология. 2003. № 4. С. 56-64].

Gontovaya L.I., Popruzhenko S.V., Nizkous I.V., 2010. Upper mantle structure in the ocean-continent transition zone: Kamchatka. Journal of Volcanology and Seismology 4 (4), 232-247. https://doi.org/10.1134/S07420463100 40020.

Gorbatov A., Dominguez J., Suarez G., Kostoglodov V., Zhao D., Gordeev E., 1999. Tomographic imaging of the P-wave velocity structure beneath the Kamchatka peninsula. Geophysical Journal International 137 (2), 269-279. https:// doi.org/10.1046/j.1365-246X.1999.t01-1-00801.x.

Grannik V.M., 2008. Geology and Geodynamics of the Southern Part of the Okhotsk Sea Region in the MesozoicCenozoic. Dal'nauka, Vladivostok, 297 p. (in Russian) [Гранник В.M. Геология и геодинамика в Южной части Охотоморского региона в мезозое-кайнозое. Владивосток: Дальнаука, 2008. 297 с.].

Jiang G., Zhao D., Zhang G., 2009. Seismic tomography of the Pacific slab edge under Kamchatka. Tectonophysics 465 (1-4), 190-203. https://doi.org/10.1016/j.tecto.2008.11.019.

Kennett B.L.N., Engdahl E.R., 1991. Traveltimes for global earthquake location and phase identification. Geophysical Journal International 105 (2), 429-465. https://doi.org/10.1111/j.1365-246X.1991.tb06724.X.

Kennett B.L.N., Engdahl E.R., Buland R., 1995. Constraints on seismic velocities in the Earth from traveltimes. Geophysical Journal International 122 (1), 108-124. https://doi.org/10.1111/j.1365-246X.1995.tb03540.x.

Koulakov I.Y., Dobretsov N.L., Bushenkova N.A., Yakovlev A.V., 2011. Slab shape in subduction zones beneath the KurileKamchatka and Aleutian arcs based on regional tomography results. Russian Geology and Geophysics 52 (6), 650-667. https://doi.org/10.1016/j.rgg.2011.05.008.

Litvinov A.F., Patoka M.G., Markovsky B.A. (Eds.), 1999. Minerals Map of the Kamchatka Region. Scale 1:500000. VSEGEI, Saint Petersburg (in Russian) [Карта полезных ископаемых Камчатской области. Масштаб 1:500000 / Ред. А.Ф. Литвинов, М.Г. Патока, Б.А. Марковский. СПб.: ВСЕГЕИ, 1999].

Moroz Y.F., Gontovaya L.I., 2003. Deep structure of the Avacha groups of volcanoes in Kamchatka. Vulkanologiya i Seismologiya (Journal of Volcanology and Seismology) (4), 3-10 (in Russian) [Мороз Ю.Ф., Гонтовая Л.И. Глубинное строение Авачинской группы вулканов на Камчатке // Вулканология и сейсмология. 2003. № 4. С. 3-10].

Moroz Y.F., Gontovaya L.I., 2017. Deep structure of Kamchatka according to the results of MT sounding and seismic tomography. Russian Journal of Pacific Geology 11 (5), 354-367. https://doi.org/10.1134/S1819714017050037.

Nizkous I., Kissling E., Sanina I., Gontovaya L., Levina V., 2007. Correlation of Kamchatka lithosphere velocity anomalies with subduction processes. In: J. Eichelberger, E. Gordeev, P. Izbekov, M. Kasahara, J. Lees (Eds.), Volcanism and subduction: the Kamchatka region. Geophysical Monograph Series, vol. 172, p. 97-106. https://doi.org/10.1029/ 172 GM09.

Nizkous I.V., Sanina I.A., Kissling E., Gontovaya L.I., 2006. Velocity properties of the lithosphere in the ocean-continent transition zone in the Kamchatka region from seismic tomography data. Izvestiya, Physics of the Solid Earth 42 (4), 286-296. https://doi.org/10.1134/S1069351306040033.

Popruzhenko S.V., Zubin M.I., 1997. Tectonics and some features of seismicity of the shelf zone of the Avacha Bay and adjacent areas. Vulkanologiya i Seismologiya (Journal of Volcanology and Seismology) (2), 74-81 (in Russian) [Попруженко С.В., Зубин М.И. Тектоника и некоторые особенности сейсмичности шельфовой зоны Авачинского залива и прилегающих районов // Вулканология и сейсмология. 1997. № 2. С. 74-81].

Seliverstov N.I., 2009. Geodynamics of the Junction Zone of the Kuril-Kamchatka and Aleutian Island Arcs. Institute of Volcanology and Seismology FEB RAS, Petropavlovsk-Kamchatsky, 291 p. (in Russian) [Селиверстов Н.И. Геодинамика зоны сочленения Курило-Камчатской и Алеутской островных дуг. Петропавловск-Камчатский: ИВиС ДВО РАН, 2009. 291 с.].

Sergeev K.F., Krasny M.L. (Eds.), 1987. Geological-Geophysical Atlas of the Kuril-Kamchatka Island System. VSEGEI, Leningrad, 36 sheets (in Russian) [Геолого-геофизический атлас Курило-Камчатской островной системы / Ред. К.Ф. Сергеев, М.Л. Красный. Л.: ВСЕГЕИ, 1987. 36 листов]. 
Sidorenko A.V. (Ed.), 1964. Geology of the USSR. Vol. 31. Kamchatka, the Kuril and Commander Islands. Geological Description. Nedra, Moscow, 733 p. (in Russian) [Геология СССР. Т. 31. Камчатка, Курильские и Командорские острова. Геологическое описание / Ред. А.В. Сидоренко. М.: Недра, 1964. 733 с.].

Zhao D., Pirajno F., Dobretsov N.L., Liu L., 2010. Mantle structure and dynamics under East Russia and adjacent regions. Russian Geology and Geophysics 51 (9), 925-938. https://doi.org/10.1016/j.rgg.2010.08.003.
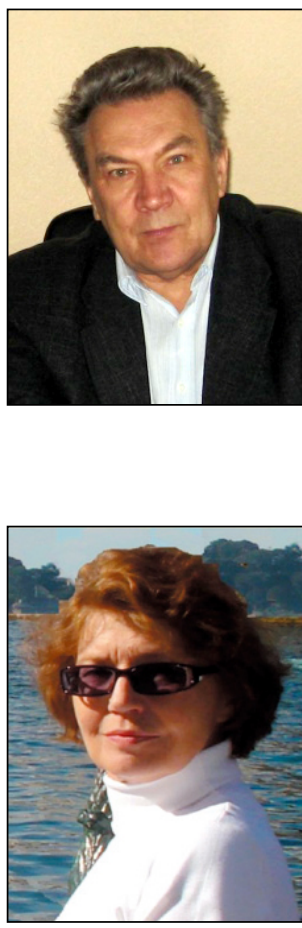

Юрий Федорович Мороз, докт. геол.-мин. наук, г.н.с.

Институт вулканологии и сейсмологии ДВО РАН

683006, Петропавловск-Камчатский, бульвар Пийпа, 9, Россия

Геологический институт СО РАН

670047, Улан-Удэ, ул. Сахьяновой, 6а, Россия

e-mail: morozyf@kscnet.ru

Yuri F. Moroz, Doctor of Geology and Mineralogy, Chief Researcher Institute of Volcanology and Seismology, Far East Branch of RAS

9 Piip Boulevard, Petropavlovsk-Kamchatsky 683006, Russia

Geological Institute, Siberian Branch of RAS

6a Sakhyanova street, Ulan-Ude 670047, Russia

Лариса Ивановна Гонтовая, канд. геол.-мин. наук, с.н.с.

Институт вулканологии и сейсмологии ДВО РАН

683006, Петропавловск-Камчатский, бульвар Пийпа, 9, Россия

e-mail: lecya@emsd.ru

Larisa I. Gontovaya, Candidate of Geology and Mineralogy, Senior Researcher Institute of Volcanology and Seismology, Far East Branch of RAS

9 Piip Boulevard, Petropavlovsk-Kamchatsky 683006, Russia 